\title{
THE IMPACT OF ORGANIZATIONAL COMMITMENT ON THE MEMBERSHIP GROWTH IN FGBMFI CHAPTER IN EAST JAVA REGION 1 IN SURABAYA
}

\author{
Aditia Djaja Tjiptobusono \\ Evangelical Theological Seminary of Indonesia - Surabaya \\ E-mail:aditiadjaja@sttii-surabaya.ac.id
}

\begin{abstract}
The title of The Impact of Organizational Commitment on The Membership Growth in FGBMFI Chapter in East Java Region 1 in Surabaya, was chosen by the author in this research study. The author wants to know whether the organizational commitment can increase the membership growth, especially in FGBMFI Chapter in East Java Region 1 in Surabaya. Pearson correlation coefficient and regression analysis, $t$-test and analysis of variance are used as the methods of analysis in this matter. Descriptive analysis was conducted to analyze the growth rate of members in FGBMFI Chapter in East Java Region 1 in Surabaya according to demographic groups. It turns out that organizational commitment has an influence, which is 39.4\%, on the member growth in FGBMFI Chapter in East Java Region 1 in Surabaya.
\end{abstract}

Keywords: Commitment Organization, Membership Growth.

\section{INTRODUCTION}

Full Gospel Business Men's Fellowship International (FGBMFI) is an organization of businessmen and Christian professionals who serve God. FGBMFI was founded in 1952, which was initiated by Demos Shakarian. FGBMFI has spread all over the world. It was in 148 countries in 2012.

The members of FGBMFI are men covering various ethnic groups, social and cultural strata. The reason FGBMFI reaches out to men is because men are heads, i.e. heads of families, who bring the whole family to Christ, and also heads of companies, who can lead, influence and bring the organization to the organization's vision.

The men are ordinary people who are made extraordinary after attending discipleship, training, teaching and training and growing spiritually and in character in their respective Chapters. Almost all members are aware of their calling as missionaries in the marketplace. Wherever FGBMFI is located, FGBMFI members spread the gospel and make people believe and witness His love. That is why FGBMFI's motto is "His Banner Over Us is Love“ (Songs 2:4). 
FGBMFI is the first fellowship to meet in neutral places such as hotels and restaurants (not in Church). This fellowship gives a place for fellowship from various church denominations and all are people who have believed in Jesus. People can gather freely to hear the good news and testimonies: that God loves people and Jesus Christ died to save, heal, bless them with His power. Traders, corporate leaders, doctors, lawyers, professionals, contractors, they are all part of this fellowship.

However, in the course of FGBMFI in Indonesia, the expected growth is still far below the National target set since the 2000s, namely 40,000 paid members and 4,000 chapters. Until this day, it has not been achieved.

The number of chapters and member developments from FGBMFI until 2019 can be seen in the table as follows:

\begin{tabular}{|c|c|c|}
\hline Tahun & Jumlah Chapter & Jumlah Paid Member \\
\hline 2012 & 113 & 776 \\
\hline 2013 & 118 & 786 \\
\hline 2014 & 123 & 727 \\
\hline 2015 & 131 & 820 \\
\hline 2016 & $\begin{array}{l}120 \\
\text { Jatim } 1=77, \text { Jatim } 2=17, \text { Jatim } 3 \\
=26\end{array}$ & $\begin{array}{l}1127 \\
\text { Jatim } 1=777, \text { Jatim } 2=138, \text { Jatim } 3=212\end{array}$ \\
\hline 2017 & $\begin{array}{l}104 \\
\text { Jatim } 1=74 \text {, Jatim } 2=12 \text {, Jatim } 3 \\
=18\end{array}$ & $\begin{array}{l}763 \\
\text { Jatim } 1=505, \text { Jatim } 2=120, \text { Jatim } 3=138\end{array}$ \\
\hline 2018 & $\begin{array}{l}105 \\
\text { Jatim } 1=75, \text { Jatim } 2=12 \text {, Jatim } 3 \\
=18\end{array}$ & $\begin{array}{l}1059 \\
\text { Jatim } 1=730, \text { Jatim } 2=125, \text { Jatim } 3=204\end{array}$ \\
\hline 2019 & $\begin{array}{l}108 \\
\text { Jatim } 1=78, \text { Jatim } 2=13 \text {, Jatim } 3 \\
=17\end{array}$ & $\begin{array}{l}1055 \\
\text { Jatim } 1=742, \text { Jatim } 2=109, \text { Jatim } 3=204\end{array}$ \\
\hline
\end{tabular}

Region targets for membership growth are required. From the table we can learn that membership growth is also increasing irregularly, and is still far from the target of $30 \%$ per year.

Comparison East Java

1 Members in 2012-2015

\begin{tabular}{|c|c|c|}
\hline Tahun & Jumlah Member & Penambahan/ Pengurangan \\
\hline 2012 & 776 & \\
\hline 2013 & 786 & ${ }^{\prime}+10=`+1,28 \%$ \\
\hline 2014 & 727 & $-59=`-7,50 \%$ \\
\hline 2015 & 820 & $‘+93=`=c+12,79 \%$ \\
\hline
\end{tabular}

Comparison East Java 1 Members in 20162019

\begin{tabular}{|c|c|c|}
\hline 2016 & 777 & \\
\hline 2017 & 763 & $-14=6-1,80 \%$ \\
\hline 2018 & 730 & $-33=-4,32 \%$ \\
\hline 2019 & 742 & ${ }^{\prime}+12=`+1,64 \%$ \\
\hline
\end{tabular}

From the table above, it can be seen that in the East Java region there are fluctuations in the number of members between minus $7.5 \%$ to plus $12.79 \%$, so it is still far from the organization's target of growth of $30 \%$. This is an issue that concerns us and it needs to be fixed. The author sees that this problem is related to organizational commitment.

One of the contributions of members to the FGBMFI organization is to behave positively, expressed in the form of a conscious contribution beyond what is formally required by the organization. Namely a high sense of belonging which is 
shown through his love and loyalty to the organization.

This should be owned by every member of FGBMFI in order to be able to contribute in service in every activity of the organization. So that members can control their own behavior, can share the priorities in their lives, that is among God, family and business. By having high discipline for each member which ultimately has an impact on the progress of the Chapter.

The main challenge for FGBMFI leaders is how to make members develop their commitment to running the organization, creating a positive climate and new innovations to face changing times. Integrating personal growth, service skills and spiritual growth.

The need for the characteristics of member commitment is measured by how they loyally serve others, look for new souls, make new souls become members, attend the Chapter meetings. The boredom in the chapter makes commitments change, the spirit to serve also begins to decline, the age factor of the members also makes them unproductive because most of their friends have become Christians, ineffective in finding new souls, as a result hindering progress and success in the future.

Commitment is one of the variables that have an important relationship in terms of serving, carrying out tasks and obligations voluntarily and with high awareness for the success of the organization. Lacking of seriousness in serving is an organizational obstacle, that is the person is unable to maintain good relations with fellow members. Therefore, it is necessary to develop members continuously. This is one form of organizational commitment that will be investigated further by the author.

From the data we obtained from the East Java Regional office, in terms of serving, not all members have the heart to be involved. Therefore, it can be concluded that only certain people are willing to serve. Similarly, in terms of attendance at Chapter's meetings and the Regional's meetings, the attendance is inconsistent. There are some people who are barely attend yearly. Although the member still pays the annual fee, there are also those who do not pay it annually. In this case, the member's commitment is questioned and the root of the problem needs to be found.

The characteristics of members who do not grow spiritually can be seen, among others, not wanting to move from their comfort zone, many people simply answer, "I am growing" when asked about their spirituality. Yet growing in Christ has special characteristics. 
If it is true that the member does not grow in Christ, the member must not change and bear no fruit. Because, changing and bearing fruit are the characteristics of a person's growth. Change and bear fruit in what way? This: character, service, giving, lifestyle, behavior, decisions, words, and so on. Not growing means not changing and not bearing fruit.

If a member, in a particular FGBMFI or fellowship for years - even decades - but the member's life has not changed significantly, I can make sure the member is not growing. Every seed planted, which represents the member, has only two possibilities, that is to grow and bear fruit, or wither and die.

The Apostle Paul taught us that in 1 Corinthians 3:6, "I planted, Apollos watered, but God gave the growth." So, growth comes from God. Or in other words, if the member does not learn or know the true God, the member will not grow. The growth of this member is directly related to the number of attendance in the fellowship held by the chapter.

If FGBMFI teaches that God is angry, punishes sinners, releases beasts, and allows accidents so that members learn something, the author believes that members' faith will not grow. Hearing such a God, members' hearts are not filled with faith and love, but fear and self-righteousness. Maturity is not measured by a person's age, let alone spiritual maturity. Members who are spiritually young are members who do not think long about the consequences of their actions and decisions. Members will be easily influenced and quickly fall into sin. Members do not have a firm stand in their accompaniment to God. Members are easily offended or irritable, who do not clearly understand what is good and what is bad. Members who are not yet spiritually mature, members who maintain their views even if they are wrong. Members who don't like holy things will feel comfortable with dirty, worldly, carnal things.

From the data obtained, there are members who are not interested in the discipleship and teaching training held by the trainers so that these members cannot grow. The low participation of some members has an impact on the spiritual growth of members. And spiritual maturity cannot be measured by the length of time being a member at FGBMFI, but by learning or knowing the true God, members will definitely change and grow in character, becoming like the character of Christ.

From the organizational stand point, FGBMFI Chapter in East Java 1 Region in Surabaya is not a church. FGBMFI Chapter in East Java 1 Region in Surabaya is called a parachurch. Parachurch is a religious 
organization that does not operate under any particular denominations. Parachurch organizations, on the other hand, only identify themselves broadly. In fact, parachurch tends to intentionally include people from different denominations. In theology, parachurch organization is called sodality.

Parachurch can be a business, a private voluntary association - a group of individuals working together to achieve a common goal - or a non profit corporation.[1]

\section{FORMULATION OF THE PROBLEM}

First, is there any influence of organizational commitment on the growth of members in FGBMFI Chapter in East Java 1 Region in Surabaya ?" Second, how much influence does organizational commitment have on the growth of members in FGBMFI Chapter in East Java 1 Region in Surabaya?"

\section{PURPOSE}

First, to determine whether or not there is an influence of organizational commitment on the growth of the number of members in FGBMFI Chapter in East Java 1 Region in Surabaya. Second, to determine the magnitude of the effect of organizational commitment on member growth in FGBMFI Chapter in East Java 1 Region in Surabaya.

\section{CONCEPTUAL FRAMEWORK}

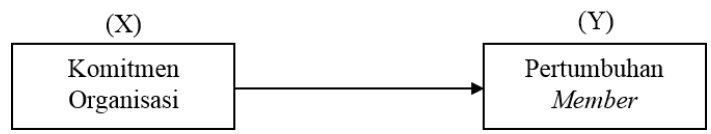

In this study the variables that will be analyzed in testing the hypothesis are as follows: $\mathrm{X}=$ Organizational Commitment; $\mathrm{Y}=$ Member Growth.

\section{RESULTS AND DISCUSSION}

The Meaning of Organizational Commitment

The term commitment is often used as a pronoun of loyalty, love, or keeping a promise. Commitment is needed not only to maintain the continuity of family ties, but also in developing an organization. Human resources (HR) who have a commitment will show an attitude of love and loyalty to their organization, which is very much needed to support the productivity of human resources (HR) and the organization.

Cut Zurnali in his book states that the general concern and key goal of the HR organizational unit is to find measurements that can accurately estimate the commitment of its employees and develop programs and activities that increase commitment to the organization.[2] It was 
further stated that a broad research study in psychology and management is about the concept and role of organizational commitment. This construct is linked to the importance of the resulting performance and turnover. Furthermore, Robert L. Mathis-John H. Jackson, argues that organizational commitment is the degree to which employees believe and accept organizational goals, and desire to stay with or leave the company which is ultimately reflected in absenteeism and employee turnover rates.[4]

Organizational commitment is a strong desire to remain as a member of a particular organization; that is the desire to strive in accordance with the wishes of the organization, as well as certain beliefs and acceptance of the values and goals of the organization. In other words, it is an attitude that reflects employee loyalty to the organization and a continuous process in which members of the organization express their concern for the organization and its success and continuous progress.[5]

According to Ghorbanpour, Dehnavi, Heyrani, namely organizational commitment has a significant positive effect on employee performance, normative commitment leaves the strongest effect on average performance, compared to affective commitment and continuance commitment.[6]

According to Arizona Riniwati Harahap, organizational commitment does not have significant influence on the employee's performance.[7] And research conducted by Subejo, Troena, Thoyib, Aisjah shows that partially organizational commitment does not have a significant effect on performance, organizational commitment built by affective commitment, ongoing commitment, and normative commitment has not been able to improve employee performance optimally.[8]

Robbins defines organizational commitment as an individual orientation to the organization that includes loyalty, identification, and involvement. Organizational commitment is an element of relationship orientation (active) between individuals and their organizations; the orientation of the relationship resulted in the individual (worker) willingly to give something; and something that is given to reflect his support for the achievement of organizational goals. High organizational commitment means that there is a high alignment with the organization.[9]

\section{Dimensions of Organizational \\ Commitment}

According to Mowday, the dimensions of organizational commitment 
are characterized by three factors, namely: strong belief and acceptance of organizational goals and values, willingness to give maximum effort for the benefit of the organization, and strong desire to maintain membership in the organization.[10]

Mowday expresses it in simple terms as follows: Organizational commitment for our purpose as the relative strength of an individual's identification with and involvement in a particular organization.[11]

Typology of organizational commitment proposed by Allen and Meyer has three components, namely: affective commitment, continuance commitment, and normative commitment. The common factor from these three components of commitment is that commitment is seen as a psychological condition that first, describes the individual's relationship with the organization, and second, has implications in the decision whether or not to continue his membership in the organization.[12]

Thus, the definition of each component of organizational commitment is as follows: First, affective commitment refers to the employee's emotional attachment to, identification with, and involvement in the organization. This means, affective commitment is related to employees' emotional attachment, employee identification to, and employee involvement in the organization. Thus, employees who have a strong affective commitment will continue to work in the organization because they really want to do so.[13]

Second, the continuance commitment relates to an awareness of the costs associated with leaving the organization. This shows that there are considerations of profit and loss in employees related to the desire to continue working or even leave the organization. Continuity commitment is in line with Becker's opinion, namely that continuance commitment is an awareness of the impossibility of choosing another social identity or alternative behavior because of the threat of great loss. Employees who mainly work based on this continuance commitment stay in the organization because they need to do so because there is no other choice.[14]

Third, normative commitment reflects a feeling of obligation to continue employment. In other words, normative commitment relates to the feeling of obligation to keep working in the organization. This means, employees who have high normative commitment feel that they ought to stay in the organization.[15] 
In addition, each component of commitment develops as a result of different experiences and has different implications. For example, a member may simultaneously feel attached to the organization and also feel obligated to remain in the organization.

Meanwhile, other members can enjoy working in the organization while realizing that they are better off staying in the organization because of the uncertain economic situation. However, other members feel wanted or needed, and are also obliged to continue working in the organization. Thus, the measurement of organizational commitment should also reflect the three components of commitment, namely affective commitment, continuance commitment, and normative commitment.

\section{MEMBERSHIP GROWTH}

Growth is one of the characteristics of an organism or a living thing. A growing church is a sign of God's healthy church. Peter C. Wagner defines church growth as anything that includes bringing people who have no personal relationship with Jesus Christ into fellowship with Him and bringing them into responsible church members.[16]

In the book of Acts, the quantitative aspect of the growth of the early church is clear. The early church which initially consisted of only 120 people (Acts $1: 15$ ) increased in number to 3000 people (Acts $2: 41)$, then every day the Lord increased their number (Acts 2:47), thus becoming 5000 people (Acts 4:4). In fact this number continues to increase where it is written as "the multitude, all the people, almost the whole city, many disciples, increased in number" (Acts 13:43-44, 48; 14:21; 16:5; 17: 4, 12). This means that a church cannot be called a growing church when it does not show an increase in the number of members. Michael Griffiths said, "We cannot build a new Temple without increasing the number of living stones.’[17]

The growing church is also marked by the formation of new areas of ministry. The growth of the early church was followed by the appointment of seven deacons to assist the work of the apostles (Acts 6:1-7). To Timothy who was in charge of the church in Ephesus, Paul gave the task of overseeing the appointment of overseers and deacons (1 Tim. 3:1-13). To Titus who was in charge of the church in Crete, Paul gave the task of appointing elders (Titus 1:6-9). These biblical data show that church growth is also marked by organizational growth.[18]

Based on these explanations, congregational growth can be defined as a balanced increase experienced by the local church, in three components, quantitatively, 
qualitatively, and organizationally. The research instrument was used to collect data and facts about the number of congregations increasing, improving the quality of congregational faith and the completeness of categorical service units within the local church

\section{CONSTRUCT}

\begin{tabular}{|c|c|c|}
\hline \multicolumn{3}{|c|}{ Konstruk Pertumbuhan Member } \\
\hline Variabel & Dimensi & Indikator \\
\hline \multirow{3}{*}{$\begin{array}{c}\text { Pertumbuhan } \\
\text { Member }\end{array}$} & Kuantitas & $\begin{array}{l}\text { Hadir dalam pertemuan yang diadakan } \\
\text { Mengikuti kegiatan organisasi } \\
\text { Berpartisipasi dalam kepanitiaan }\end{array}$ \\
\hline & Kualitas & $\begin{array}{l}\text { Memiliki ide untuk pengembangan pelayanan } \\
\text { Berkontribusi secara moril dan materi } \\
\text { Bertanggung jawab menyelesaikan pelayanan }\end{array}$ \\
\hline & Organisasi & $\begin{array}{l}\text { Jumlah hadir bertambah } \\
\text { Perlu tempat pertemuan lebih besar } \\
\text { Kegiatan pelayanan lebih beragam }\end{array}$ \\
\hline
\end{tabular}

\begin{tabular}{|c|c|c|}
\hline \multicolumn{3}{|c|}{ Konstruk Komitmen Organisasional } \\
\hline Variabel & Dimensi & Indikator \\
\hline \multirow{3}{*}{$\begin{array}{l}\text { Komitmen } \\
\text { Organisasional }\end{array}$} & Komitmen Afektif & $\begin{array}{l}\text { Terikat secara emosional } \\
\text { Bagian dari organisasi } \\
\text { Rasa memiliki } \\
\text { Setia di organisasi }\end{array}$ \\
\hline & Komitmen Normatif & $\begin{array}{l}\text { Rasa tidak nyaman meninggalkan organisasi } \\
\text { Loyalitas kepada organisasi } \\
\text { Tidak etis meninggalkan organisasi } \\
\text { Rasa tanggung jawab pada tugas }\end{array}$ \\
\hline & Komitmen Kontinuan & $\begin{array}{l}\text { Membutuhkan organisasi } \\
\text { Pilihan yang terbaik } \\
\text { Sudah berbuat banyak untuk organisasi } \\
\text { Paling menguntungkan dari yang lain }\end{array}$ \\
\hline
\end{tabular}

\section{HYPOTHESIS}

Based on the theoretical basis that has been disclosed above, in this section the author provides a hypothesis as a reference in the research to be carried out. As we know that a hypothesis is an initial presumption that needs to be verified through field research. In researching the effect of organizational commitment on the growth of the number of members in FGBMFI Chapter in East Java 1 Region in Surabaya, the authors formulate the hypothesis (H1) of this dissertation as follows: "It is suspected that organizational commitment can affect the growth of the number of members in FGBMFI Chapter in East Java 1 Region in Surabaya ", which verified through further research which will be discussed in the next chapter.

This study collects data through field research. The paradigm used is the quantitative paradigm, where this study uses statistical equipment to analyze existing data derived from literature observations and field research.

After conducting initial observations and literature studies, the authors then determine the Research Question. This is where the problem formulation comes from. From the formulation of the problem, the writer conducts a theoretical study and then formulates a hypothesis.

After that, the author selects the data by determining the population and determining the sample and the desired respondent's criteria. Then the next step is to make a questionnaire that is designed based on the formulation of the problem that has 
been determined and based on a construct that is in accordance with the theoretical basis.

The results obtained were first tested for validity and reliability. These two tests are absolutely necessary requirements before we conduct data analysis. Validity test can be defined as a measure of how strong or accurate a measuring instrument is in performing its measuring function. The higher the validity of a variable, the more the measuring instrument hits its target and the more it shows what it should show. The next test is the reliability test.

Then the reliability test shows the extent to which the measuring instrument can be trusted or relied on. Reliability here can mean that no matter how many times these variables are asked to different respondents, the results will not deviate too far from the average respondent's answers to these variables or in other words, reliability can show the consistency of a measuring instrument in measuring the same symptoms.

Steps to test the validity and reliability that have been carried out with results that meet the requirements; the next step is to perform regression analysis. Regression parameters were tested simultaneously using Analysis of Variance (Anova). This ANOVA is used to test the accuracy of the estimated regression line.

\section{POPULATIONS AND SAMPLE}

This data collection is taken from a population. The population, as described by Sandjaja and Heriyanto, is the whole object that is the center of research attention and a place to generalize research findings. The object under study can be anything, be it people, objects, events or symptoms. In general, research will not raise the entire population as the object under study, but it is enough to take a sample from the population.[19]

In this study, the populations to be studied are members of FGBMFI Chapter in East Java 1 Region in Surabaya, namely members who are part of a family, both in their capacity as nuclear and non-nuclear families. However, the author will limit the research to members who are over the age of seventeen and have been a member for 3 years, on the grounds that members under that age are assumed to be not old enough and not yet competent enough to answer the questionnaire that will be given by the author.

The sample, according to Sugiyono, is part of the number and characteristics possessed by the population. If the population is too large so that it is not possible to study the whole, the researcher can use samples taken from the population. For this reason, samples taken from the population must be truly representative or 
can represent the characteristics of the entire population.[20]

\section{CONCLUSION}

Conclusions in this study are based on individual categories, in this case the respondents, and conclusions based on hypotheses answered through a series of test tools.

\section{Conclusion Based on Individual Categories}

This section describes respondents based on age and occupation categories only. Regarding gender, all of them are male, because all members of this FGBMFI organization are men. Although there were three women who answered, in the questionnaire via Google Form, they were asked to stop here. This is one of the advantages of the questionnaire provided by Google Forms, besides there are other advantages.

Respondents based on age, the majority are 51-60 years old, followed by 41-50 years old group, then over 61 years old group. Most of this age group has been directly involved in the management of FGBMFI Chapter in East Java 1 Region in Surabaya.

The following respondents were based on occupation; it was found that the majority of members of FGBMFI Chapter in East Java 1 Region in Surabaya were entrepreneurs or entrepreneurs. It is evident that in terms of paying annual fees and other contributions, the members of FGBMFI Chapter in East Java 1 Region in Surabaya are actively taking part in this.

\section{Conclusion Based on Hypotheses}

The hypothesis in this study is 'It is suspected that organizational commitment can affect the growth in the number of members in FGBMFI Chapter in East Java 1 Region in Surabaya. Based on the results of Anova, it was found that organizational commitment had a significant effect of 4.475. And the value of the coefficient of determination is $39.4 \%$, the remaining $60.6 \%$ is influenced by other variables, which are not discussed in this study (H1 is accepted). The conclusion is that there is an effect of organizational commitment on the growth of the number of members in the East Java Regional 1 FGBMFI in Surabaya.

\section{REFERENCES}

[1]https://www.onlinechristiancolleges.co $\mathrm{m} / \mathrm{faq} /$ what-is-parachurch/

[2] Complete explanation in Cut Zurnali, Learning Organization, Competency, Organizational Commitment, and Customer Orientation_ Knowledge Worker: Future Human Resource Management Research Framework (Bandung: Unpad Press, 2010). https://feb.ug.ac.id/id/berita/2464tantangan-source-human-saat-ini-dan- 
masa- Depan, accessed on August 3, 2020, at 08.55 .

[3] Peter W. Hom, Rodger W. Griffeth, Employee Turnover (Cincinnati: Southwestern, 1995), 12.

[4] Robert L. Mathis dan John H. Jackson, Human Resource Management (Jakarta: Salemba Empat, 2006), 37.

[5] Fred Luthans, Organizational Behavior, translator V. A. Yuwono, et al. (Yogyakarta: ANDI, 2006), 27.

[6] Zahra Ghorbanpour, Hasan Dehghan Dehnavi, Forough Heyrani, "Investigating the Effect of Organizational Commitment on Performance of Auditors in the Community of Certified Accountants," Interdisciplinary Journal of Contemporary Research In Business, Vol. 5, No.1 (2014): 199-209.

[7] Dika Arizona, Harsuko Riniwati, Nuddin Harahap, "Analysis of the Influence of Leadership Style, Work Motivation and Organizational Commitment on Employee Performance," APi STUDENT JOURNAL, Vol. I, No. 1 (2013): 1-11.

[8] Endang Suswati and Arif Budianto, "Organizational Commitment as One of the Determinants of Employee Performance," Proceedings of the National Seminar and Call for Papers Sancall 2013, Surakarta (2013): 1-9.

[9] Stephen P. Robbins, Timothy A. Judge, Organizational Behavior (Jakarta: Salemba Empat, 2014), 116.

[10] R. T. Mowday, R. M. Steers, and L. W. Porter, "The Measurement of Organizational Commitment," Journal of Vocational Behavior, Vol. 14 (1979): 224247.
[11] Richard T. Mowday, Lyman W. Porter, Richard M. Steers, Employee-Organization Linkages: The Psychology of Commitment, Absenteeism, and Turnover (Massachusetts: Academic Press, 2013), 27.

[12] N. J. Allen and J. P. Meyer, "The Measurement and Antecedents of Affective, Continuance and Normative Commitment," Journal of Occupational Psychology, 63, 1, (1990): 1-18.

[13] The full explanation is in Sukanto Reksohadiprojo and T. Hani Handoko's book, Corporate Organization Theory, Structure and Behavior (Yogyakarta: BPFE, 1996).

[14] Reksohadiprojo, et al., Company Organization Theory, Structure and Behavior. Yuyun Elizabeth Patras, "The Influence of Leadership Behavior, Organizational Justice, and Work Involvement on Lecturer Organizational Citizenship Behavior," Pedagogical, Scientific Journal of Education, Vol. 1, No. 1 (2017): 8-14.

[15] Sukanto Reksohadiprojo and T. Hani Handoko, Company Organization Theory, Structure and Behavior (Yogyakarta: BPFE, 1996).

[16] C. Peter Wagner, Your Church Can Grow (Malang: Wheat Mas, 1997), 11.

[17] Michael Griffiths, The Church and Today's Vocations (Jakarta: BPK Gunung Mulia, 1991), 80.

[18] Dapot Tua Simanjuntak, Joseph Christ Santo, "The Influence of the Pastor's Life on Church Growth," Kharismata, Journal of Pentecostal Theology, Vol. 2, No. 1 (2019): 28-41. 
Theological Journal Kerugma

E-ISSN: 2622-1039

P-ISSN: 2621-8038

[19] B. Sandjaja \& Albertus Heriyanto, Research Guide (Jakarta: Prestasi Pustaka Publisher, 2011), 183-184.

[20] Sugiyono, Qualitative Quantitative Research Methods and R\&D (Jakarta: Alfabeta, 2008), 81. 